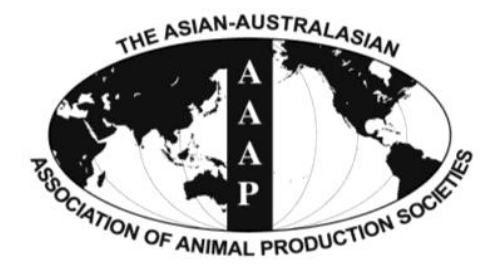

Asian Australas. J. Anim. Sci.

Vol. 26, No. 8 : 1102-1110 August 2013

http://dx.doi.org/10.5713/ajas.2013.13098

www.ajas.info

pISSN 1011-2367 elSSN 1976-5517

\title{
In vitro Fermentation, Digestion Kinetics and Methane Production of Oilseed Press Cakes from Biodiesel Production
}

\author{
S. M. Olivares-Palma, S. J. Meale, L. G. R. Pereira ${ }^{1}$, F. S. Machado ${ }^{1}$, H. Carneiro ${ }^{1}$, \\ F. C. F. Lopes ${ }^{1}$, R. M. Maurício ${ }^{2}$, and A. V. Chaves* \\ Faculty of Veterinary Science, University of Sydney, Sydney, NSW 2006, Australia
}

\begin{abstract}
Following the extraction of oil for biodiesel production, oilseed press cakes are high in fat. As the dietary supplementation of fat is currently considered the most promising strategy of consistently depressing methanogenesis, it follows that oilseed press cakes may have a similar potential for $\mathrm{CH}_{4}$ abatement. As such, this study aimed to characterise the nutritive value of several oilseed press cakes, glycerine and soybean meal (SBM) and to examine their effects on in vitro ruminal fermentation, digestion kinetics and $\mathrm{CH}_{4}$ production. Moringa press oil seeds exhibited the greatest in sacco effective degradability (ED) of DM and CP $(\mathrm{p}<0.05)$. In vitro gas production $(\mathrm{ml} / \mathrm{g}$ digested $\mathrm{DM})$ was not affected $(\mathrm{p}=0.70)$ by supplement at $48 \mathrm{~h}$ of incubation. In vitro $\mathrm{DMD}$ was increased with the supplementation of glycerine and SBM at all levels of inclusion. Moringa oilseed press cakes produced the lowest $\mathrm{CH}_{4}(\mathrm{mg} / \mathrm{g}$ digested DM) at 6 and $12 \mathrm{~h}$ of incubation $(\mathrm{p}<0.05)$. The findings suggest that moringa oilseed press cake at $400 \mathrm{~g} / \mathrm{kg} \mathrm{DM}$ has the greatest potential of the oilseed press cakes examined in this study, to reduce $\mathrm{CH}_{4}$ production, without adversely affecting nutrient degradability. (Key Words: Methane, Oilseed Press Cake, Ruminal Fermentation, Supplementation)
\end{abstract}

\section{INTRODUCTION}

Methane is the primary greenhouse gas produced from livestock production, accounting for $37 \%$ of total anthropogenic $\mathrm{CH}_{4}$ emissions (FAO, 2006). Methane production is essential for effective degradation of organic matter, but also represents an energy loss of 2 to $12 \%$ gross energy intake (Johnson and Johnson, 1995). Consequently, strategies which can mitigate $\mathrm{CH}_{4}$ emissions, not only benefit the environment, but are of benefit to the animal as well.

Increasing interest in biodiesel, as a replacement for fossil fuels, has oilseeds, suitable for direct human consumption, being used for the production of renewable fuels. As such, the use of non-traditional grains and oilseeds, which do not compete directly with human consumption, are becoming attractive alternatives for the production of ethanol and biodiesel, respectively.

\footnotetext{
* Corresponding Author: Alex V. Chaves. Tel: + 61-2-9036-9312, Fax: +61-2-9351-3957, E-mail: alex.chaves@ sydney.edu.au

${ }^{1}$ Embrapa Dairy Cattle, Rua Eugênio do Nascimento, 610, Juiz de Fora, MG, Brazil.

${ }^{2}$ Universidade Federal de São João del Rei, São João del-Rei, MG, Brazil.

Submitted Feb. 12, 2013; Accepted May 5, 2013; Revised May 6, 2013
}

Biodiesel production yields two important by-products, oilseed press cakes and glycerine (Schröder and Südekum, 1999). The recent transition to the use of mechanical extraction produces oilseed press cakes with significantly higher oil contents leading to their use as energy feeds (Südekum, 2007). Similarly, glycerine, which forms the backbone of triglycerides and phospholipids in plants and animals, has been included in the diets of ruminant livestock for over 50 years at rates of up to $200 \mathrm{~g} / \mathrm{kg} \mathrm{DM}$ depending on purity (Johns, 1953; Schröder and Südekum, 1999).

Currently, increasing the lipid content of ruminant diets is considered the most effective way of consistently depressing ruminal methanogenesis (Grainger and Beauchemin, 2011). As oilseed press cakes are rich in fat, it follows that these biodiesel by-products could potentially exhibit a similar response, in terms of $\mathrm{CH}_{4}$ abatement, although there effects on digestion are largely unknown. Our objectives were therefore, to characterise the nutritive value of press cakes from moringa, castor, cotton, palm kernel, radish and sunflower and glycerine following oil extraction for biodiesel production and to examine their effects on in vitro ruminal fermentation, digestion kinetics and $\mathrm{CH}_{4}$ production. 


\section{MATERIALS AND METHODS}

\section{Substrates}

Seven different oilseed press cakes commonly used for biodiesel production were tested in the in sacco study. These were: castor (Family Euphorbiaceae; Ricinus communis), cotton (Family Malvaceae; Gossypium hirsutum L), moringa (Family Moringaceae; Moringa oleifera Lam.), palm kernel (Family Euphorbiaceae; Elaeis guineensis, Jacq), radish (Family Brassicaceae; Raphanus sativus L. var. Oleiformes) and sunflower (Family Asteraceae; Helianthus annuus). Soybean meal [SBM, Family Fabaceae (alt. Leguminoseae; Glycine max)] and beard grass (Brachiaria brizantha) were used as a control.

The castor oilseed press cake was purchased from a Brazilian plant located in the municipality of Iraquara Ecodiesel, BA, and transported to Embrapa Semiarid, where it was detoxified using calcium hydroxide $\left[\mathrm{Ca}(\mathrm{OH})_{2}\right]$ diluted in water at a ratio of $9 \mathrm{~L}$ of water $/ \mathrm{kg}$ of $\mathrm{Ca}(\mathrm{OH})_{2}$ at a ratio of $60 \mathrm{~g}$ of $\mathrm{Ca}(\mathrm{OH})_{2} / \mathrm{kg}$ castor oilseed press cake. After treatment, the castor oilseed press cake was packed into a $200 \mathrm{~L}$ polyethylene drum for $24 \mathrm{~h}$ and allowed to dry in the sun for $12 \mathrm{~h}$.

The remaining oilseed press cakes were obtained from Embrapa Dairy Cattle in Juiz de Fora (MG, Brazil). Glycerine was only tested in vitro and was obtained from ADM (Archer Daniels Midland) Company of Brazil Ltd (Rondonópolis, MT). Beard grass (Brachiaria brizantha; control) was harvested at $30 \mathrm{~d}$ of re-growth at the EMBRAPA Dairy Cattle Research Centre (Coronel Pacheco, MG, Brazil) located at $21^{\circ} 35^{\prime} \mathrm{S}, 43^{\circ} 15^{\prime} \mathrm{W}$ and $435 \mathrm{~m}$ above sea level. The DM and chemical composition of the oilseed press cake and beard grass samples were analysed (Table 1). The DM content of glycerine had been previously determined as $863.5 \mathrm{~g} / \mathrm{kg}$. Samples were dried and ground to $2 \mathrm{~mm}$. Approximately $5 \mathrm{~g} \mathrm{DM}$ of sample (Table 1) from each source was weighed into nylon bags $(100 \times 200 \mathrm{~mm}$; pore size $50 \mu \mathrm{m}$ ) sealed and stored at room temperature.

\section{In sacco study}

Three rumen fistulated lactating Holstein-Zebu crossbred dairy cows were fed a diet consisting of beard grass forage supplemented with $2 \mathrm{~kg}$ of concentrate (22 $\mathrm{g} / \mathrm{kg} \mathrm{CP}$ and $12.6 \mathrm{~g} / \mathrm{kg}$ NDF in DM) on a DM basis for the in sacco study. In sacco incubation measured the ruminal degradation of DM and crude protein (CP) of dietary treatments. For each cow, 24 weighted bags were placed at the bottom of the rumen, with three bags removed after 3, 6 , 12, 24, 48 and $96 \mathrm{~h}$ of incubation. The $0 \mathrm{~h}$ bags were not placed in the rumen.

After removal from the rumen at the designated incubation times, nylon bags (including $0 \mathrm{~h}$ bags) containing diet residues were washed for $30 \mathrm{~min}$ on a cold rinse cycle $\left(20^{\circ} \mathrm{C}\right)$ in a washing machine and then dried at $55^{\circ} \mathrm{C}$ for $48 \mathrm{~h}$. Dried bags were weighed and residues were ground through a $1 \mathrm{~mm}$ screen for DM and CP analysis.

Digestion kinetics: Digestion curves for each data set were used to evaluate the in sacco degradation kinetics of dietary treatments in the rumen. Disappearance of DM and CP was analysed using a non-linear model as described by Lopez et al. (1999) to determine the fractional disappearance rate $\left(k, \mathrm{~h}^{-1}\right)$ and potential degradation $(P)$ according to:

$$
P=A+B\left(1-\mathrm{e}^{-k(t-L)}\right)
$$

where $A$ is the soluble fraction (proportion of each constituent, washed out of bags at $t=0 \mathrm{~h}$ ), $B$ is the insoluble degradable fraction, $t$ is the time (h) and $L$ is the lag phase (h). Effective degradability (ED) was calculated from the kinetic parameters obtained from exponential adjustment assuming a fractional passage rate $\left(k_{p}\right)$ of $0.02,0.05$ and

Table 1. Dry matter contents and chemical composition of the experimental diets

\begin{tabular}{|c|c|c|c|c|c|c|c|c|c|}
\hline & \multirow[b]{2}{*}{ DM (g/kg) } & \multicolumn{8}{|c|}{$\mathrm{DM}(\mathrm{g} / \mathrm{kg})$} \\
\hline & & $\mathrm{CP}$ & NDF & $\begin{array}{c}\text { Non-fibrous } \\
\text { carbohydrates }\end{array}$ & $\mathrm{ADF}$ & ADL & Ash & $\begin{array}{c}\text { Ether } \\
\text { extract }\end{array}$ & ADIN \\
\hline Beard grass (control) & 903.4 & 121.1 & 652.2 & 92.1 & 354.6 & 41.1 & 111.2 & 23.4 & 1.8 \\
\hline Soybean meal & 869.9 & 528.4 & 234.9 & 152.4 & 243.8 & 125.9 & 66.0 & 18.3 & 23.8 \\
\hline \multicolumn{10}{|l|}{ Press oil seeds } \\
\hline Castor & 912.6 & 320.2 & 467.4 & 58.6 & 383.4 & 154.4 & 110.0 & 43.8 & 20.3 \\
\hline Cotton & 922.8 & 549.9 & 277.0 & 64.5 & 247.7 & 109.9 & 68.3 & 40.3 & 13.5 \\
\hline Moringa & 905.2 & 577.1 & 202.7 & 85.6 & 80.5 & 33.3 & 49.8 & 84.8 & 3.0 \\
\hline Palm kernel & 928.7 & 356.9 & 391.4 & 61.6 & 364.5 & 167.5 & 79.5 & 110.6 & 8.9 \\
\hline Radish & 935.6 & 393.7 & 279.7 & 4.9 & 154.2 & 69.6 & 41.3 & 280.4 & 5.6 \\
\hline Sunflower & 914.5 & 329.4 & 439.7 & 27.6 & 384.0 & 120.4 & 41.3 & 162.0 & 7.6 \\
\hline SD & 20.18 & 151.79 & 149.98 & 44.35 & 114.70 & 49.97 & 27.92 & 89.31 & 8.01 \\
\hline
\end{tabular}

$\mathrm{CP}=$ Crude protein; $\mathrm{NDF}=$ Neutral detergent fibre; $\mathrm{ADF}=$ Acid detergent fibre; $\mathrm{ADL}=$ Acid detergent lignin.

$\mathrm{ADIN}=$ Acid detergent insoluble nitrogen $\mathrm{SD}=$ Standard deviation 
$0.08 \mathrm{~h}^{-1}$ :

$$
\mathrm{ED}=A+B \times\left(k /\left(k+k_{p}\right)\right)
$$

The different turnover rates $\left(k_{p}\right)$ used here were based on maintenance feeding, medium and high production dairy cows (Chaves et al., 2006b), respectively.

\section{In vitro incubations}

Substrates: The substrates used for in vitro incubations were beard grass (Brachiaria brizantha; control) or beard grass supplemented with oilseed press cake or glycerine $(0.864 \mathrm{w} / \mathrm{v}$ pure $)$ in ratios of 1,000:0, 900:100, 800:200 and 600:400, for each treatment, respectively. Feed ingredients were dried at $55^{\circ} \mathrm{C}$ for $24 \mathrm{~h}$ and then ground to pass a $1 \mathrm{~mm}$ screen and mixed to obtain the 24 treatments. Each in vitro incubation was conducted as per Meale et al. (2012). Even at the $400 \mathrm{~g} / \mathrm{kg}$ level of inclusion, the glycerine was fully absorbed onto the feed, leaving no free liquid. The entire incubation procedure was repeated twice (i.e., two incubation runs $\times$ three replicates per treatment, resulting in a total of six replicate vials per treatment).

Inoculum: Inoculum for the in vitro incubation was obtained from three ruminally fistulated cows grazing beard grass supplemented with $2 \mathrm{~kg}$ of concentrate $(22 \mathrm{~g} / \mathrm{kg} \mathrm{CP}$ and $12.6 \mathrm{~g} / \mathrm{kg} \mathrm{NDF}$ in DM). Rumen fluid was collected $2 \mathrm{~h}$ before morning milking from 4 distinct sites in the rumen, filtered through 4 layers of cheesecloth, combined in equal portions from each animal and immediately transported in a pre-warmed Thermos ${ }^{\circledR}$ flask to the laboratory. Inoculum was prepared by mixing rumen fluid and a mineral buffer with $0.5 \mathrm{ml}$ of cysteine sulphide solution (Vitti et al., 1999) in a ratio of $1: 3$. Inoculum $(25 \mathrm{ml})$ was then transferred into pre-loaded, pre-warmed $\left(39^{\circ} \mathrm{C}\right)$ vials under a stream of $\mathrm{O}_{2^{-}}$ free $\mathrm{N}$ gas. Vials were sealed and placed on an orbital shaker rack set at 120 oscillations per min in an incubator set at $39^{\circ} \mathrm{C}$.

Determination of total gas, methane concentration and in vitro dry matter disappearance (IVDMD): Net gas production of each vial was measured at $6,12,24$ and $48 \mathrm{~h}$ of incubation with a water displacement apparatus (Fedorak and Hrudey, 1983). At $6 \mathrm{~h}$ and $12 \mathrm{~h}$ prior to gas measurement, headspace gas was sampled from each vial with a $20 \mathrm{ml}$ syringe and immediately transferred into a 5.9 $\mathrm{ml}$ evacuated Exetainer ${ }^{\circledR}$ (Labco Ltd., High Wycombe, Buckinghamshire, UK), which was then analysed for $\mathrm{CH}_{4}$ concentration by gas chromatography. Methane was expressed as mg of $\mathrm{CH}_{4} / \mathrm{g}$ of DM disappeared and total net gas production as $\mathrm{ml} / \mathrm{g}$ of incubated DM. After gas was sampled for $\mathrm{CH}_{4}$ and total gas production was measured at $48 \mathrm{~h}$ of incubation, the fermentation vials were opened and the $\mathrm{pH}$ of the culture was measured using a $\mathrm{pH}$ meter
(Orion Model 260A, Fisher Scientific, Toronto, ON, Canada). The ANKOM $^{\circledR}$ bags with the residues were then removed from the bottles, rinsed thoroughly with distilled water and dried at $55^{\circ} \mathrm{C}$ for $48 \mathrm{~h}$ to constant weight to estimate IVDMD.

Determination of ammonia- $N$ and VFA: A subsample $(1.6 \mathrm{ml})$ of the culture media from each vial was transferred to $2 \mathrm{ml}$ micro-centrifuge tubes and centrifuged at $14,000 \times g$ for $10 \mathrm{~min}$ at $4^{\circ} \mathrm{C}$ (Spectrafuse $16 \mathrm{M}$, National Labnet Co., Edison, NJ, USA) to precipitate particulate matter and protein. The supernatant was transferred into $2 \mathrm{ml}$ microcentrifuge tubes and analysed for ammonia-N. In addition, a subsample $(1.5 \mathrm{ml})$ of each vial was collected, acidified with $300 \mu \mathrm{l}$ of metaphosphoric acid $(0.25 ; \mathrm{w} / \mathrm{v})$, and centrifuged as previously described for ammonia-N analysis. Supernatant was frozen at $-20^{\circ} \mathrm{C}$ until analysed for VFA concentrations. The $0 \mathrm{~h}$ samples were also analysed for ammonia-N and VFA to calculate net ammonia-N and net total VFA production (Holtshausen et al., 2009).

\section{Chemical analysis}

Duplicate samples of each treatment and control diet were analysed for NDF and ADF using Van Soest et al. (1991) procedures modified for an ANKOM 200/220 Fiber Analyzer $^{\circledR}$ (ANKOM Technol. Corp., Fairport, NY, USA), with heat-stable $\alpha$-amylase. Concentrations of NDF and ADF were expressed inclusive of residual ash; NDF was corrected for $\mathrm{CP}$ and ash. Ash content was determined after $2 \mathrm{~h}$ of oxidation at $600^{\circ} \mathrm{C}$ in a muffle furnace (method 942.05; AOAC, 1990). Samples were re-ground using a ball grinder (Mixer Mill MM2000, Retsch, Haan, Germany) for determination of total $\mathrm{N}$ and the ADIN by combustion (method 990.03; AOAC, 1990). Crude protein was calculated as $\mathrm{N} \times 6.25$. Ether extract (EE) content was ascertained by extraction with diethyl ether (method 920.39; AOAC, 1990) procedure modified for an ANKOM XT10 Extraction System $^{\circledR}$ (ANKOM Technol. Corp., Fairport, NY, USA). Non-fibrous carbohydrate (NFC) was calculated as:

$$
\mathrm{NFC}=1,000-(\mathrm{CP}+\mathrm{NDF}+\mathrm{EE}+\mathrm{ash}) \quad(\text { Mertens, 2002). }
$$

\section{Statistical analyses}

Univariate procedure in SAS was used to test for normal distribution of the data. Data were analysed as a randomized complete design using PROC MIXED (SAS, 2013). For the in vitro study, oilseed press cakes from biodiesel production treatment means for each level were compared against the control using the least squares mean linear hypothesis test (LSMEANS/DIFF) with the Dunnett adjustment with significance declared if $\mathrm{p}<0.05$. For the in sacco study, data were analysed using a non-linear least-square procedure 
Table 2. Experimental diets dry matter degradation characteristics (in $\mathrm{g} / \mathrm{kg}$ ) as defined by soluble (A), degradable insoluble (B), undegradable residual $(C=1,000-\mathrm{A}-\mathrm{B})$ pools, fractional disappearance rate $\left(k, \mathrm{~h}^{-1}\right)$, effective degradability $\left(\mathrm{ED}_{\mathrm{DM}}\right)$ and lag phase $(\mathrm{h})$

\begin{tabular}{|c|c|c|c|c|c|c|c|c|}
\hline & \multirow{2}{*}{ A } & \multirow{2}{*}{$\mathrm{B}$} & \multirow{2}{*}{$\mathrm{C}$} & \multirow{2}{*}{$k$} & \multicolumn{3}{|c|}{ Effective degradability $\left(\mathrm{ED}_{\mathrm{DM}}\right)$} & \multirow{2}{*}{ Lag $(\mathrm{h})$} \\
\hline & & & & & $\left(k_{p}=0.02\right)$ & $\left(k_{p}=0.05\right)$ & $\left(k_{p}=0.08\right)$ & \\
\hline Bread grass (control) & $168.3^{\mathrm{d}}$ & $471.0^{c}$ & $360.7^{c}$ & $0.046^{\mathrm{de}}$ & $492.1^{\mathrm{f}}$ & $389.6^{\mathrm{g}}$ & $336.6^{\mathrm{g}}$ & $0.8^{\mathrm{b}}$ \\
\hline Soybean meal & $413.7^{\mathrm{a}}$ & $586.3^{\mathrm{a}}$ & $0.0^{\mathrm{g}}$ & $0.052^{\mathrm{d}}$ & $862.5^{\mathrm{b}}$ & $727.8^{\mathrm{c}}$ & $656.4^{\mathrm{c}}$ & $2.8^{\mathrm{a}}$ \\
\hline \multicolumn{9}{|l|}{ Press oil seeds } \\
\hline Castor & $189.3^{\mathrm{d}}$ & $299.0^{\mathrm{d}}$ & $511.7^{\mathrm{a}}$ & $0.082^{c}$ & $429.5^{\mathrm{h}}$ & $375.2^{\mathrm{h}}$ & $340.9^{\mathrm{g}}$ & $3.5^{\mathrm{a}}$ \\
\hline Cotton & $274.4^{\mathrm{bc}}$ & $514.0^{\mathrm{b}}$ & $211.6^{\mathrm{d}}$ & $0.030^{\mathrm{e}}$ & $584.9^{\mathrm{d}}$ & $469.2^{\mathrm{e}}$ & $416.3^{\mathrm{e}}$ & $2.8^{\mathrm{a}}$ \\
\hline Moringa & $397.7^{\mathrm{a}}$ & $517.0^{\mathrm{b}}$ & $85.3^{\mathrm{f}}$ & $0.256^{\mathrm{a}}$ & $873.8^{\mathrm{a}}$ & $824.5^{\mathrm{a}}$ & $785.1^{\mathrm{a}}$ & $0.4^{\mathrm{b}}$ \\
\hline Palm kernel & $250.4^{\mathrm{c}}$ & $282.0^{\mathrm{d}}$ & $467.6^{\mathrm{b}}$ & $0.087^{\mathrm{c}}$ & $478.7^{\mathrm{g}}$ & $428.2^{f}$ & $396.1^{\mathrm{f}}$ & $2.8^{\mathrm{a}}$ \\
\hline Radish & $411.0^{\mathrm{a}}$ & $468.0^{c}$ & $121.0^{\mathrm{e}}$ & $0.117^{\mathrm{b}}$ & $810.7^{c}$ & $739.2^{\mathrm{b}}$ & $689.4^{\mathrm{b}}$ & $0.7^{\mathrm{b}}$ \\
\hline Sunflower & $304.4^{\mathrm{b}}$ & $220.0^{\mathrm{e}}$ & $475.6^{\mathrm{b}}$ & $0.248^{\mathrm{a}}$ & $507.2^{\mathrm{e}}$ & $485.8^{\mathrm{d}}$ & $468.5^{\mathrm{d}}$ & $3.3^{\mathrm{a}}$ \\
\hline SE & 13.9 & 13.8 & 8.6 & 0.0073 & 3.5 & 3.9 & 4.9 & 0.28 \\
\hline
\end{tabular}

${ }^{\mathrm{a}-\mathrm{g}}$ Within column, means lacking a common letter differ $(\mathrm{p}<0.05)$. SE $=$ Standard error.

(PROC NLIN; SAS, 2103) to provide estimates for A, B and $\mathrm{k}$ calculated from DM and CP disappearance data. Data for all variables were analysed using the PROC MIXED procedure of SAS (2013) where treatments as fixed terms and cow and cow by treatment interaction as random effects. Significance was declared if $\mathrm{p}<0.05$.

\section{RESULTS}

\section{In sacco study}

Dry matter digestion kinetics: The distribution of DM between soluble, degradable insoluble and undegradable residual fractions, disappearance rates $\left(k, \mathrm{~h}^{-1}\right)$ and effective degradability ( $\mathrm{ED}_{\mathrm{DM}}$; a prediction of degradation in vivo) of each supplement are summarised in Table 2. Soluble DM fraction was higher $(\mathrm{p}<0.05)$ for SBM, moringa and radish oilseed press cake than other treatments. Degradable insoluble DM was highest $(\mathrm{p}<0.05)$ for SBM, whereas the undegradable residual DM fraction was highest $(\mathrm{p}<0.01)$ for castor oilseed press cake when compared to other oilseed press cakes and beard grass (control). Kinetic data showed rapid degradation rates $(k)$ of moringa oilseed press cake and sunflower and slow degradation of cotton oilseed press cake and beard grass. Moringa oilseed press cake had the highest $(\mathrm{p}<0.01) \mathrm{ED}_{\mathrm{DM}}$ among treatments, closely followed by SBM and radish oilseed press cake, respectively (Table 2).

Crude protein digestion kinetics: Soluble CP fractions varied across all treatments $(\mathrm{p}<0.05)$. Radish and palm nut oilseed press cakes had the highest soluble fractions $(\mathrm{p}<0.05$; Table 3$)$. The insoluble degradable pool was highest for SBM and lowest for castor oilseed press cake $(\mathrm{p}<0.05)$. Conversely, castor oilseed press cakes and beard grass had the highest undegradable residual pool whereas, SBM and cotton oilseed press cake had the lowest $(\mathrm{p}<0.05)$. Sunflower oilseed press cake exhibited the greatest $(\mathrm{p}<0.05)$ fractional rate of CP disappearance when compared to all other treatments. Cotton and SBM had CP degradation rates $(k)$ lower (average $0.04 \mathrm{~h}^{-1}$ ) than that of the beard grass control $(\mathrm{p}<0.05)$. Effective degradability of $\mathrm{CP}\left(\mathrm{ED}_{\mathrm{CP}}\right)$ was greatest $(\mathrm{p}<0.01)$ for sunflower oilseed press cake, despite differences in distribution between pools, degradation rates

Table 3. Experimental diets crude protein degradation characteristics (in $\mathrm{g} / \mathrm{kg}$ ) as defined by soluble (A), degradable insoluble (B), undegradable residual $(\mathrm{C}=1,000-\mathrm{A}-\mathrm{B})$ pools, fractional disappearance rate $\left(k, \mathrm{~h}^{-1}\right)$, effective degradability (ED) and lag phase (h)

\begin{tabular}{|c|c|c|c|c|c|c|c|c|}
\hline & \multirow{2}{*}{ A } & \multirow{2}{*}{ B } & \multirow{2}{*}{$\mathrm{C}$} & \multirow{2}{*}{$k$} & \multicolumn{3}{|c|}{ Effective degradability $\left(\mathrm{ED}_{\mathrm{CP}}\right)$} & \multirow{2}{*}{ Lag } \\
\hline & & & & & $\left(k_{p}=0.02\right)$ & $\left(k_{p}=0.05\right)$ & $\left(k_{p}=0.08\right)$ & \\
\hline Beard grass (control) & $193.4^{\mathrm{g}}$ & $385.0^{\text {ef }}$ & $421.6^{\mathrm{a}}$ & $0.068^{\mathrm{e}}$ & $485.4^{\mathrm{f}}$ & $408.4^{\mathrm{h}}$ & $363.8^{\mathrm{g}}$ & $2.2^{\mathrm{c}}$ \\
\hline Soybean meal & $340.0^{\mathrm{e}}$ & $660.0^{\mathrm{a}}$ & $0.0^{\mathrm{d}}$ & $0.038^{\mathrm{f}}$ & $859.8^{\mathrm{c}}$ & $680.8^{\mathrm{f}}$ & $593.9^{e}$ & $4.5^{\mathrm{a}}$ \\
\hline \multicolumn{9}{|l|}{ Press oil seeds } \\
\hline Castor & $249.9^{f}$ & $351.0^{\mathrm{f}}$ & $399.1^{\mathrm{a}}$ & $0.106^{\mathrm{d}}$ & $543.8^{\mathrm{e}}$ & $486.5^{\mathrm{g}}$ & $448.0^{\mathrm{f}}$ & $3.0^{\mathrm{b}}$ \\
\hline Cotton & $475.3^{\mathrm{b}}$ & $524.7^{\mathrm{c}}$ & $0.0^{\mathrm{d}}$ & $0.041^{\mathrm{f}}$ & $833.1^{\mathrm{d}}$ & $715.1^{\mathrm{e}}$ & $655.7^{\mathrm{d}}$ & $3.3^{\mathrm{b}}$ \\
\hline Moringa & $369.9^{\mathrm{d}}$ & $583.0^{\mathrm{b}}$ & $47.1^{\mathrm{c}}$ & $0.286^{\mathrm{b}}$ & $912.1^{\mathrm{a}}$ & $861.1^{\mathrm{b}}$ & $819.5^{\mathrm{b}}$ & $0.3^{\mathrm{d}}$ \\
\hline Palm kernel & $485.1^{\mathrm{ab}}$ & $420.0^{\mathrm{de}}$ & $94.9^{\mathrm{b}}$ & $0.103^{\mathrm{d}}$ & $836.5^{\mathrm{d}}$ & $767.5^{\mathrm{d}}$ & $721.1^{\mathrm{c}}$ & $0.3^{\mathrm{d}}$ \\
\hline Radish & $496.7^{\mathrm{a}}$ & $444.0^{\mathrm{d}}$ & $59.3^{c}$ & $0.208^{\mathrm{c}}$ & $901.0^{\mathrm{b}}$ & $853.2^{\mathrm{c}}$ & $815.7^{\mathrm{b}}$ & $0.5^{\mathrm{d}}$ \\
\hline Sunflower & $397.0^{c}$ & $533.0^{c}$ & $70.0^{\mathrm{bc}}$ & $0.425^{\mathrm{a}}$ & $906.1^{\mathrm{ab}}$ & $873.6^{\mathrm{a}}$ & $845.1^{\mathrm{a}}$ & $0.3^{\mathrm{d}}$ \\
\hline SE & 7.5 & 13.2 & 9.8 & 0.0092 & 3.4 & 2.8 & 3.7 & 0.21 \\
\hline
\end{tabular}

\footnotetext{
a-h Within column, means lacking a common letter differ $(\mathrm{p}<0.05)$. SE $=$ Standard error.
} 
and lag times (Table 3). Lag phases resembled patterns for $\mathrm{DM}$, with longer $(\mathrm{p}<0.01)$ lag phase for SBM than the oilseed press cakes.

\section{In vitro incubations}

Replacing $B$. brizantha with castor oilseed press cake at $400 \mathrm{~g} / \mathrm{kg} \mathrm{DM}$ decreased gas production $(\mathrm{ml} / \mathrm{g} \mathrm{DM})$ at $48 \mathrm{~h}$ ( $\mathrm{p}<0.01$; Table 4). However, no differences $(\mathrm{p}=0.70)$ among treatments were observed in cumulative gas production, when expressed as $\mathrm{ml} / \mathrm{g}$ digested DM. Glycerine produced the greatest amount of $\mathrm{CH}_{4}(\mathrm{mg} / \mathrm{g}$ digested DM; $\mathrm{p}<0.01$ ) at both 6 and $12 \mathrm{~h}$ when included at 100 and $200 \mathrm{~g} / \mathrm{kg}$ DM. Whereas, moringa oilseed press cakes, exhibited the lowest $(\mathrm{p}<0.01) \mathrm{CH}_{4}$ production when compared to control, regardless of the inclusion level. Total VFA concentration did not differ $(\mathrm{p} \geq 0.30)$ between control and oilseed press cakes. However, there were differences ( $p$ $=0.04$ ) among treatments, where $400 \mathrm{~g} / \mathrm{kg} \mathrm{DM}$ cotton oilseed press cake exhibited the highest total VFA concentration and $400 \mathrm{~g} / \mathrm{kg}$ DM sunflower the lowest. The proportion of acetate in the total VFA increased $(\mathrm{p}<0.01)$ for castor oilseed press cake included at $400 \mathrm{~g} / \mathrm{kg}$ DM yet decreased $(p<0.01)$ for glycerine at $200 \mathrm{~g} / \mathrm{kg} \mathrm{DM}$ and 400 $\mathrm{g} / \mathrm{kg}$ DM when compared to the control. Similarly, glycerine replacing $B$. brizantha at $200 \mathrm{~g} / \mathrm{kg}$ DM and 400 $\mathrm{g} / \mathrm{kg}$ DM produced higher $(\mathrm{p}<0.01)$ propionate levels compared to control. Castor oilseed press cake replacing grass at $400 \mathrm{~g} / \mathrm{kg} \mathrm{DM}$ decreased $(\mathrm{p}=0.02)$ the proportion of butyrate in total VFA compared to control.

Replacing the grass control with glycerine and SBM, regardless of the proportion, improved IVDMD $(\mathrm{p}<0.01$; $\mathrm{g} / \mathrm{kg}$ ) compared to the control. However, castor supplemented at $200 \mathrm{~g} / \mathrm{kg} \mathrm{DM}$ and $400 \mathrm{~g} / \mathrm{kg}$ DM reduced $(\mathrm{p}<0.01)$ IVDMD. Ammonia-N (mg/dl) increased with the inclusion of all levels of radish oilseed press cake, $100 \mathrm{~g} / \mathrm{kg}$ DM castor oilseed press cake and $400 \mathrm{~g} / \mathrm{kg}$ DM of cotton, moringa and sunflower oilseed press cakes and SBM.

\section{DISCUSSION}

\section{Dry matter in sacco characteristics}

Lignification limits microbial access to structural polysaccharides in the cell wall resulting in slower digestion (Waghorn et al., 2003). Results of the current study support this, as there was a linear trend for supplements with higher concentrations of dietary NDF to exhibit a lower effective degradability of DM $\left(E D_{\mathrm{DM}}\right.$; Figure 1). For example, the highest rapidly soluble fraction of DM was found in moringa oilseed press cake which also had the lowest concentrations of NDF and ADL (DM basis). Castor press oils seeds contained high levels of NDF and ADL, resulting in a low disappearance of the soluble fraction of DM, although the rate of DM disappearance $(k$, $\mathrm{h}^{-1}$ ) was moderate. High disappearance of the degradable fraction of DM in the rumen is nutritionally favourable as the supply of energy to rumen microbes increases (Chaves et al., 2006a).

A greater $\mathrm{ED}_{\mathrm{DM}}$, such as that observed in moringa oilseed press cake, is preferential as the nutrients are more readily available and can therefore be more effectively utilised by the animal. In the current study, castor and palm

Table 4. Effects of increasing levels of oilseed press cakes, glycerine and soybean meal (SBM) as replacement of Brachiaria brizantha (control) on $48 \mathrm{~h}$ fermentation characteristics and in vitro methane production

\begin{tabular}{|c|c|c|c|c|c|c|c|c|c|c|c|c|c|c|c|c|c|c|c|c|c|c|c|c|c|c|c|}
\hline & \multicolumn{25}{|c|}{ Proportion Brachiaria brizantha:press oil seed or glycerine (g/kg DM) } & \multirow[b]{3}{*}{ SE } & \multirow[b]{3}{*}{$E \begin{array}{c}p- \\
\text { value }\end{array}$} \\
\hline & \multirow{2}{*}{ 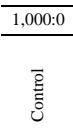 } & \multicolumn{8}{|c|}{$900: 100$} & \multicolumn{8}{|c|}{$800: 200$} & \multicolumn{8}{|c|}{ 600:400 } & & \\
\hline & & 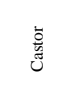 & 总 & 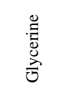 & 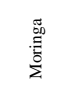 & 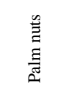 & 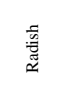 & $\sum_{\substack{n \\
\text { W }}}$ & 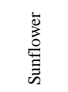 & 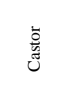 & 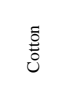 & $\begin{array}{l}\text { 莺 } \\
\text { 정 }\end{array}$ & 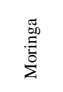 & 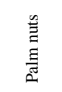 & 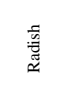 & 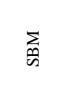 & 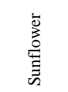 & 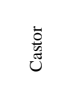 & 菅 & 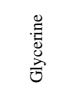 & 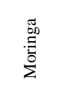 & 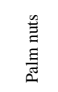 & 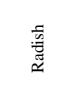 & 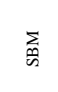 & 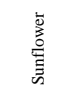 & & \\
\hline \multicolumn{28}{|c|}{ Gas production (m//g DM) } \\
\hline $6 \mathrm{~h}$ & 25.2 & 22.8 & 26.8 & 28.4 & 24.0 & 25.8 & 26.3 & 27.0 & 25.1 & 22.0 & 27.1 & $30.3^{*}$ & 24.4 & 26.1 & 28.3 & 26.9 & 26.2 & $19.5^{*}$ & 27.7 & 26.4 & 21.1 & 23.9 & 30.0 & $33.0^{*}$ & 27.1 & 1.16 & $<0.01$ \\
\hline $12 \mathrm{~h}$ & 42.4 & 35.9 & 44.6 & 48.7 & 36.9 & 42.9 & 41.6 & 44.6 & 41.5 & $32.8^{*}$ & 45.5 & 59.8 & 35.9 & 40.7 & 44.1 & 44.2 & 43.0 & $26.4 *$ & 45.5 & $53.2^{*}$ & $27.3^{*}$ & 36.0 & 44.6 & $53.1^{*}$ & 44.2 & 2.24 & $<0.01$ \\
\hline $24 \mathrm{~h}$ & 62.6 & 54.1 & 63.7 & 65.7 & 51.8 & 62.2 & 59.2 & 63.0 & 58.7 & 47.7 & 64.8 & 80.1 & 49.6 & 57.2 & 61.7 & 62.1 & 58.7 & $34.9^{*}$ & 63.4 & $90.1^{*}$ & $36.0^{*}$ & 49.5 & 60.5 & 73.1 & 59.9 & 4.45 & $<0.01$ \\
\hline $48 \mathrm{~h}$ & 82.3 & 74.6 & 82.7 & 83.6 & 64.8 & 82.8 & 76.6 & 82.1 & 76.4 & 63.7 & 84.4 & 95.2 & 60.4 & 74.5 & 78.9 & 81.4 & 74.4 & $45.0^{*}$ & 82.0 & 98.9 & 48.3 & 63.9 & 73.2 & 96.1 & 72.3 & 8.50 & $<0.01$ \\
\hline $\begin{array}{l}48 \mathrm{~h} \\
(\mathrm{~m} / \mathrm{g} \text { digested DM) }\end{array}$ & 161.7 & 158.6 & 161.1 & 140.4 & 134.6 & 153.9 & 149.7 & 148.6 & 146.7 & 146.5 & 160.9 & 156.3 & 121.4 & 147.1 & 153.2 & 144.7 & 142.7 & 120.7 & 153.6 & 145.3 & 93.1 & 126.5 & 141.2 & 154.0 & 137.0 & 16.44 & 0.70 \\
\hline \multicolumn{28}{|c|}{ Methane (mg/g digested DM) } \\
\hline $6 \mathrm{~h}$ & 2.0 & 1.9 & 2.1 & $2.7 *$ & 1.8 & 2.3 & 2.1 & 2.0 & 2.2 & 1.7 & 2.3 & $3.0^{*}$ & 1.8 & 2.3 & $2.7^{*}$ & 2.3 & 2.3 & 1.8 & 2.5 & 2.4 & $1.4^{*}$ & $1.9^{*}$ & 3.0 & $2.6^{*}$ & 2.3 & 0.13 & $<0.01$ \\
\hline $12 \mathrm{~h}$ & 5.0 & 4.6 & 5.3 & $6.6^{*}$ & 4.1 & 5.2 & 4.9 & 4.9 & 5.1 & 4.2 & 5.6 & $9.3^{*}$ & 3.8 & 5.1 & 6.0 & 5.3 & 5.2 & 3.8 & 5.9 & $7.7 *$ & $2.5^{*}$ & 4.4 & 5.8 & 6.0 & 5.3 & 0.31 & $<0.01$ \\
\hline \multicolumn{28}{|c|}{ Fermentation characteristics } \\
\hline Culture $\mathrm{pH}$ & 6.3 & 6.41 & 6.37 & 6.25 & 6.44 & 6.32 & 6.36 & 6.36 & $6.47 *$ & 6.45 & 6.31 & $5.97 *$ & $6.53^{*}$ & 6.42 & 6.42 & 6.39 & $6.52^{*}$ & $6.67 *$ & 6.42 & $5.68^{*}$ & $6.64^{*}$ & 6.51 & $6.52^{*}$ & 6.39 & $6.60^{*}$ & 0.03 & $<0.01$ \\
\hline $\begin{array}{l}\text { Total VFA } \\
(\mathrm{m} M)\end{array}$ & 26.1 & 18.5 & 21.9 & 20.9 & 9.3 & 12.5 & 10.9 & 9.8 & 18.2 & 13.2 & 32.9 & 15.2 & 13.9 & 10.6 & 9.4 & 9.3 & 9.1 & 15.8 & 29.8 & 13.0 & 10.9 & 7.8 & 10.9 & 14.9 & 6.7 & 5.06 & 0.04 \\
\hline \multicolumn{28}{|c|}{$\mathrm{VFA}(\mathrm{mmol} / 100 \mathrm{mmol})$} \\
\hline Acetate (A) & 65.3 & 66.9 & 65.0 & 66.9 & 68.6 & 70.3 & 66.1 & 69.6 & 66.2 & 71.2 & 66.5 & $63.4^{*}$ & 68.2 & 67.5 & 65.6 & 69.8 & 64.7 & $76.2^{*}$ & 71.4 & $56.1^{*}$ & 68.1 & 65.9 & 66.1 & 64.8 & 58.9 & 2.60 & $<0.01$ \\
\hline Propionate (P) & 14.8 & 14.2 & 14.8 & 16.7 & 15.6 & 14.0 & 14.6 & 15.0 & 14.4 & 13.1 & 14.4 & $20.4^{*}$ & 14.4 & 13.7 & 14.1 & 12.3 & 15.9 & 11.5 & 12.1 & $27.7 *$ & 16.5 & 15.7 & 14.1 & 15.9 & 17.9 & 1.24 & $<0.01$ \\
\hline Butyrate & 19.9 & 18.9 & 20.1 & 16.4 & 15.7 & 15.6 & 19.3 & 15.3 & 19.3 & 15.7 & 19.1 & 16.2 & 17.3 & 18.8 & 20.2 & 17.9 & 19.3 & $12.3^{*}$ & 16.4 & 16.2 & 15.4 & 18.4 & 19.8 & 19.2 & 23.1 & 1.71 & 0.02 \\
\hline A:P ratio & 4.4 & 4.8 & 4.5 & 4.4 & 4.8 & 5.4 & 4.7 & 4.8 & 4.7 & 5.8 & 4.6 & 3.3 & 4.9 & 5.2 & 4.8 & 6.1 & 4.3 & $7.1^{*}$ & 6.2 & $2.1 *$ & 4.3 & 4.4 & 4.7 & 4.2 & 3.6 & 0.54 & $<0.01$ \\
\hline$\underset{(\mathrm{mg} / \mathrm{dl})}{\text { Ammonia }} \mathrm{N}$ & 20.8 & $43.2^{*}$ & 25.4 & 31.6 & 28.3 & 35.1 & $37.7 *$ & 32.4 & 36.2 & 30.1 & 32.1 & 24.0 & 27.5 & 28.2 & $39.2^{*}$ & 30.9 & 27.7 & 30.3 & $41.1^{*}$ & 15.2 & $40.3^{*}$ & 32.4 & $44.7^{*}$ & $38.2^{*}$ & $38.0^{*}$ & 3.68 & $<0.01$ \\
\hline $\begin{array}{l}\text { IVDMD } \\
(\mathrm{g} / \mathrm{kg} \text { DM })\end{array}$ & 502.1 & 470.8 & 514.4 & $596.5^{*}$ & 483.7 & 535.4 & 515.1 & $552.9^{*}$ & 520.5 & $432.0^{*}$ & 520.6 & $612.1^{*}$ & 497.9 & 505.3 & 510.7 & $561.9^{*}$ & 528.0 & $379.6^{*}$ & 527.0 & $682.4 *$ & 517.3 & 511.6 & 518.4 & $623.0^{*}$ & 533.2 & 10.35 & $<0.01$ \\
\hline
\end{tabular}

IVDMD = In vitro dry matter disappearance. VFA = Volatile fatty acids.

* Means within a row differ significantly from the control $(\mathrm{p}<0.05)$. SE $=$ Standard error. 


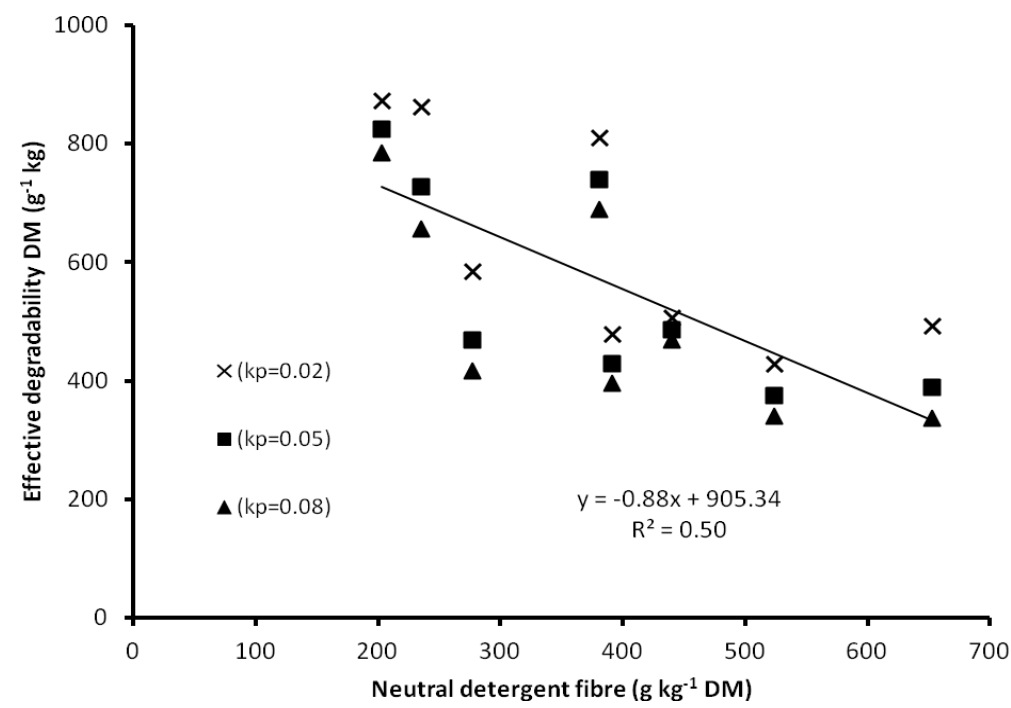

Figure 1. Effective degradability of dry matter $(\mathrm{DM})\left(\mathrm{ED}_{\mathrm{DM}}\right)$ of oilseed press cakes, soybean meal and glycerine in terms of neutral detergent fibre (NDF) concentration ( $\mathrm{g} / \mathrm{kg} \mathrm{DM})$.

kernel oilseed press cakes were the least degradable supplements. Both of these oilseed press cakes had high ADL and NDF concentrations $(\mathrm{g} / \mathrm{kg})$ indicating a lower nutritive value. This is in agreement with Gralak et al. (1997) which reported low rumen degradability of both DM and $\mathrm{CP}$ in palm seed meal. The presence of seed shells has also been reported to negatively affect degredation (Makkar et al., 2008) and whilst this may have had an effect in this study, the presence of seeds shells was not quantified.

\section{Crude protein in sacco characteristics}

The effective degradability of $\mathrm{CP}\left(\mathrm{ED}_{\mathrm{CP}}\right)$ exhibited a similar trend to that of the $\mathrm{ED}_{\mathrm{DM}}$ whereby, increasing concentrations of NDF lead to lower $\mathrm{ED}_{\mathrm{CP}}$ (Figure 2) potentially having detrimental effects on microbial protein synthesis, as ruminally degradable protein supplies peptides, amino acids and $\mathrm{NH}_{3}-\mathrm{N}$ derived from proteolysis (Promkot et al., 2007). Moringa oilseed press cake exhibited the highest $\mathrm{ED}_{\mathrm{CP}}$ and a high rate of $\mathrm{CP}$ disappearance in the current study, most likely a result of its low NDF concentration and high $\mathrm{CP}$ content. The $\mathrm{CP}$ contents of moringa oilseed press cake $(577.1 \pm 151.8 \mathrm{~g} / \mathrm{kg} \mathrm{DM})$ were higher in the present study than previously reported for moringa oilseed press cakes (317 g/kg DM; Anwar and Rashid, 2007). The moringa used in the current study was completely devoid of bark, which may account for the differences observed. However, the $\mathrm{ED}_{\mathrm{CP}}$ of moringa oilseed press cake was comparable to that of sunflower, despite the considerably lower $\mathrm{CP}$ content of sunflower oilseed press cake. This may be a result of the higher soluble fraction of $\mathrm{CP}$ in sunflower oilseed press cake which suggests, that although the $\mathrm{CP}$ content is lower, it is

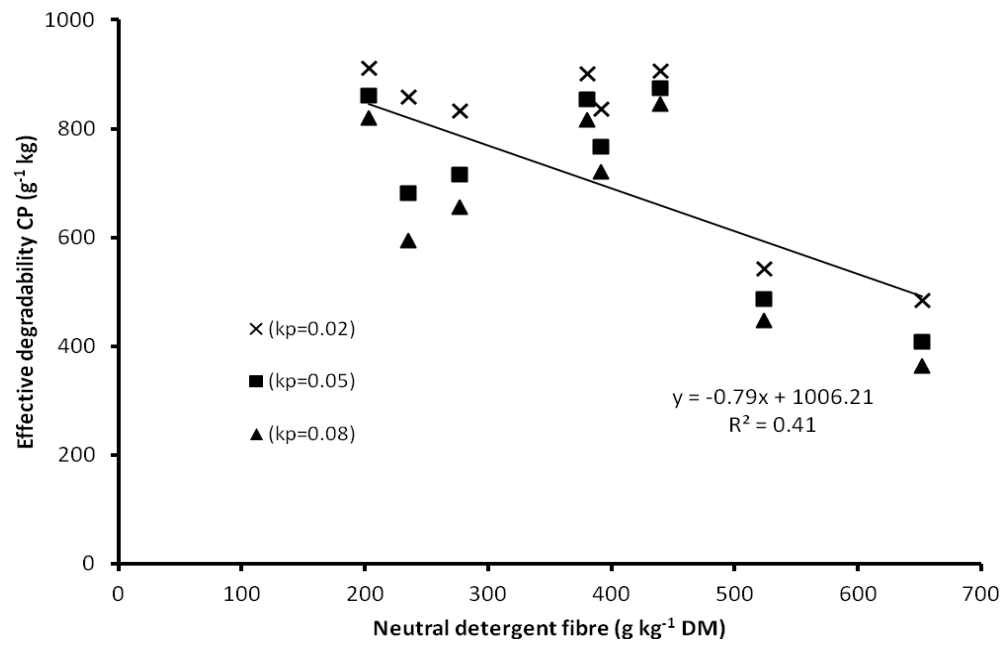

Figure 2. Effective degradability of crude protein $(\mathrm{CP})\left(\mathrm{ED}_{\mathrm{CP}}\right)$ of oilseed press cakes, soybean meal and glycerine in terms of neutral detergent fibre (NDF) concentration $(\mathrm{g} / \mathrm{kg} \mathrm{DM})$. 
still readily available.

Conversely, despite having a high CP content, cotton oilseed press cake had one of the lowest $\mathrm{ED}_{\mathrm{CP}}$. Gohl (1998) reported cottonseed meal had relatively low rumen degradability, making it a good source of by-pass protein. Similarly, Sarwatt et al. (2004) reported a higher CP content in cotton oilseed press cake compared to moringa leaf meal (320 vs $274 \mathrm{~g} / \mathrm{kg} \mathrm{DM}$ ), yet the soluble and degradable insoluble fractions of cotton oilseed press cake were significantly lower than for moringa leaf meal. The authors attributed this to a dilution of $\mathrm{CP}$ in the cotton oilseed press cake as a result of the inclusion of cotton seeds hulls during processing.

Variation in protein degradability may also reflect different proportions of structural and non-structural protein and carbohydrate fractions, which in turn affects their solubility and bio-availability. Castor oilseed press cake had a CP concentration similar to that of sunflower oilseed press cake, yet they exhibited the lowest and highest CP disappearance of all treatments, respectively. The $\mathrm{ED}_{\mathrm{DM}}$ of castor oilseed press cake was also low indicating that nutrients are not readily available from this biodiesel byproduct. Conversely, Nagalakshmi et al. (2010) compared the inclusion of castor seed cake and groundnut cake (10 $\mathrm{g} / \mathrm{kg}$ DM) in a complete lamb diet and concluded that castor seed cake did not affect nitrogen digestibility but increased the digestibility of crude fibre and NDF, when compared to groundnut cake.

\section{In vitro incubations}

Feed degradability is an essential component in determining the nutritive value of a feed. In the current study, the efficiency and extent of feed degradability was similar across all supplement types as reflected by the in vitro gas production. Increasing the level of supplementation of oilseed press cakes, SBM or glycerine to $400 \mathrm{~g} / \mathrm{kg}$ did not affect gas production, when expressed as a function of digested DM, regardless of the supplement type. This suggests that the inclusion of these supplements in a forage based diet does not detrimentally affect digestion in a manner which is commonly associated with lipid supplementation, such as a reduction in in vitro bacterial growth and protozoal populations (Doreau and Chilliard, 1997), disturbances which can reduce gas production and DM digestion.

The supplementation of moringa and castor oilseed press cakes at $400 \mathrm{~g} / \mathrm{kg}$ DM lowered gas production (mg/g DM). Interestingly, moringa oilseed press cake also had the lowest NDF and ADL contents of all treatments. These components, when present at high levels, are generally considered to impede microbial degradation of feeds (Johnson and Johnson, 1995). The presence of toxins, such as cationic polyelectrolyte proteins in moringa oilseed press cakes, which have been shown to exhibit antibacterial properties and bind strongly with rumen microbes, could potentially provide an explanation. At low levels, these proteins can protect feed proteins from degradation in the rumen, but, at high levels these proteins can inhibit rumen fermentation (Makkar et al., 2007) explaining the depression in gas production, although the levels of toxins present in each supplement were not measured in this study.

In vitro $\mathrm{CH}_{4}$ production is usually linked to digestibility, whereby highly digestible feeds are generally considered to produce more $\mathrm{CH}_{4}$ (Lee et al., 2011). This is supported by the results of the current study, where glycerine and SBM increased IVDMD $(\mathrm{g} / \mathrm{kg})$ above that of the control at all levels of inclusion. Correspondingly, glycerine produced the highest amount of $\mathrm{CH}_{4}(\mathrm{mg} / \mathrm{g}$ digested MD) at all levels of inclusion, with SBM showing an increase in $\mathrm{CH}_{4}$ at 400 $\mathrm{g} / \mathrm{kg} \mathrm{DM}$, suggesting that $\mathrm{CH}_{4}$ production was indeed a reflection of diet digestibility. Although it is generally accepted that enteric fermentation of glycerine shifts the end products of fermentation towards the production of propionate, it is unlikely to form a hydrogen sink as occurs following carbohydrate fermentation and thus, a similar reduction in $\mathrm{CH}_{4}$ production was not observed. The inclusion of supplements which reduced the A:P ratio did not necessarily lower $\mathrm{CH}_{4}$ production. For example, inclusion of moringa oilseed press cake at $400 \mathrm{~g} / \mathrm{kg}$ DM yielded the lowest amount of $\mathrm{CH}_{4}$, expressed in terms of digested DM yet, had an A:P ratio comparable to the control. Similarly, glycerine supplemented at this level had the lowest $\mathrm{A}: \mathrm{P}$ ratio, yet exhibited the highest $\mathrm{CH}_{4}$ production at $12 \mathrm{~h}$, suggesting an alternative method of $\mathrm{CH}_{4}$ suppression. Likewise, supplementing castor oilseed press cakes at $400 \mathrm{~g} / \mathrm{kg}$ DM exhibited the highest A:P ratio yet no differences were observed in $\mathrm{CH}_{4}$ production $(\mathrm{mg} / \mathrm{g} \mathrm{DM})$. These results are in agreement with Avila et al. (2011) which also observed a reduction in the A:P ratio without observing a reduction in in vitro $\mathrm{CH}_{4}(\mathrm{mg} / \mathrm{g}$ digested DM) when substituting increasing levels of glycerol for barley. Interestingly, castor oilseds press cakes had similar gas production to glycerine, indicating that a reduction in $\mathrm{CH}_{4}$ production was not a result of inhibited digestion. Although the castor oilseed press cakes used in the current study were detoxified, inclusion above $100 \mathrm{~g} / \mathrm{kg}$ DM in a forage based diet reduced IVDMD with potentially detrimental effects on animal performance. Additionally, the use of castor oilseed press cake in ruminant diets is generally limited at $10 \mathrm{mg} / \mathrm{kg}$, expressed in terms of castoroil plant husks, due to the presence of the toxic glycoprotein, ricin (Madeira et al., 2011) indicating limited potential for inclusion of this supplement in ruminant diets.

Replacement of $B$. brizantha with oilseed press cakes, SBM or glycerine at up to $400 \mathrm{~g} / \mathrm{kg}$ DM did not exhibit a similar effect to the supplementation of high levels of lipids 
in terms of reduced carbohydrate digestion. However, these supplements, with the exception of moringa oilseed press cakes at $400 \mathrm{~g} / \mathrm{kg} \mathrm{DM}$, failed to inhibit $\mathrm{CH}_{4}$ production and are therefore considered to show limited $\mathrm{CH}_{4}$ abatement potential. Supplementation of Moringa oilseed press cake included at $400 \mathrm{~g} / \mathrm{kg}$ DM was different in that, it lowered $\mathrm{CH}_{4}$ production, expressed as $\mathrm{g} / \mathrm{mg}$ digested $\mathrm{DM}$, without compromising nutrient degradation and consequently, exhibited the highest nutritive value of the supplements examined in this study.

\section{ACKNOWLEDGEMENTS}

The authors wish to thank RumenGases Research Project funded by Conselho Nacional de Desenvolvimento Científico e Tecnológico (CNPq - Edital REPENSA); Embrapa (PECUS-RumenGases) and Fundação de Amparo a Pesquisa do Estado de Minas Gerais (FAPEMIG - PPM).

\section{REFERENCES}

Anwar, F., and U. Rashid. 2007. Physio-chemical characteristics of moringa oleifera seeds and seed oil from a wild provenance of Pakistan. Pak. J. Bot. 39:1443-1453.

AOAC. 1990. Official methods of analysis (15th edn). in Association of Official Analytical Chemists. Gaithersburg, MD.

Avila, J. S., A. V. Chaves, M. Hernandez-Calva, K. A. Beauchemin, S. M. McGinn, Y. Wang, O. M. Harstad, and T. A. McAllister. 2011. Effects of replacing barley grain in feedlot diets with increasing levels of glycerol on in vitro fermentation and methane production. Anim. Feed Sci. Technol. 166-167:265268.

Buckner, C. D., G. E. Erickson, T. L. Mader, S. L. Colgan, K. K. Karges, and M. L. Gibson. 2007. Optimum levels of dry distillers grains with solubles for finishing beef steers. Pages 36-38 in Neb. Beef Cattle Reports.

Chaves, A. V., L. C. Thompson, A. D. Iwaasa, S. L. Scott, M. E. Olson, C. Benchaar, D. M. Veira, and T. A. McAllister. 2006a. Effect of pasture type (alfalfa vs. grass) on methane and carbon dioxide production by yearling beef heifers. Can. J. Anim. Sci. 86:409-418.

Chaves, A. V., S. L. Woodward, G. C. Waghorn, I. M. Brookes, and J. L. Burke. 2006b. Effects on performance of sulla and/or maize silages supplements for grazing dairy cows. Asian-Aust. J. Anim. Sci. 19:1271-1282.

Doreau, M., and Y. Chillard. 1997. Digestion and metabolism of dietary fat in farm animals. Br. J. Nutr. 78:S15-S35.

FAO. 2006. World Agriculture: towards 2030/2050. Interim Report. Rome, Italy.

Fedorak, P. M., and S. E. Hrudey. 1983. A simple apparatus for measuring gas-production by methanogenic cultures in serum bottles. Environ. Technol. Lett. 4:425-432.

Gohl, B. 1998. Tropical feeds Version 8, Rome.

Grainger, C., and K. A. Beauchemin. 2011. Can enteric methane emissions from ruminants be lowered without lowering their production? Anim. Feed Sci. Technol. 166-167:308-320.

Gralak, M. A., T. Kamalu, M. A. Von Keyserlingk, and G. W.
Kulasek. 1997. Rumen dry matter and crude protein degradability of extracted or untreated oilseeds and leucaena leucocephala leaves. Arch Tierernahr 50:173-185.

Holtshausen, L., A. V. Chaves, K. A. Beauchemin, S. M. McGinn, T. A. McAllister, P. R. Cheeke, and C. Benchaar. 2009. Feeding saponin-containing Yucca schidigera and Quillaja saponaria to decrease enteric methane production in dairy cows. J. Dairy Sci. 92:2809-2821.

Johns, A. T. 1953. Fermentation of glycerol in the rumen of sheep. N.Z. J. Sci. Technol. 35:362-269.

Johnson, K. A., and D. E. Johnson. 1995. Methane emissions from cattle. J. Anim. Sci. 73:2483-2492.

Lee, S. -Y., S. -M. Lee, Y. -B. Cho, D. -K. Kam, S. -C. Lee, C. -H. Kim, and S. Seo. 2011. Glycerol as a feed supplement for ruminants: In vitro fermentation characteristics and methane production. Anim. Feed Sci. Technol. 166-167:269-274.

Lopez, S., J. France, M. S. Dhanoa, F. Mould, and J. Dijkstra. 1999. Comparison of mathematical models to describe disappearance curves obtained using the polyester bag technique for incubating feeds in the rumen. J. Anim. Sci. 77:1875-1888.

Madeira, Jr, J. V., J. A. Macedo, and G. A. Macedo. 2011. Detoxification of castor bean residues and the simultaneous production of tannase and phytase by solid-state fermentation using Paecilomyces variotii. Bioresour. Technol. 102:73437348.

Makkar, H. P. S., G. Francis, and K. Becker. 2007. Bioactivity of phytochernicals in some lesser-known plants and their effects and potential applications in livestock and aquaculture production systems. Animal 9:1371-1391.

Makkar, H. P. S., G. Francis, and K. Becker. 2008. Protein concentrate from Jatropha curcas screw-pressed seed cake and toxic and antinutritional factors in protein concentrate. J. Sci. Food Agric. 88:1542-1548

Meale, S. J., A. V. Chaves, J. Baah, and T. A. McAllister. 2012. Methane production of different forages in in vitro ruminal fermentation. Asian-Aust. J. Anim. Sci. 25:86-91.

Mertens, D. R. 2002. Gravimetric determination of amylasetreated neutral detergent fiber in feeds with refluxing in beakers or crucibles: collaborative study. J. AOAC Int. 85:1217-1240.

Nagalakshimi, D., K. Dhanakshmi, and D. Himabindu. 2010. Replacement of groundnut cake with castor seed cake on performance, nutrient utilisation, immunocompetence and carcass characterisitcs in lambs. in Proc. XXVI Wolrd Buiatrics Congress, Santiago, Chile.

Promkot, C., M. Wanapat, and P. Rowlinson. 2007. Estimation of ruminal degradation and intestinal digestion of tropical protein resources using the nylon bag technique and the three-step in vitro procedure in dairy cattle on rice straw diets. Asian-Aust. J. Anim. Sci. 20:1849-1857.

Sarwatt, S. V., M. S. Milangha, F. P. Lekule, and N. Madallam. 2004. Moringa oleifera and cottonseed cake as supplements for smallholder dairy cows fed Napier grass. Livestock Res. for Rural Develop. 16 Art. \#38. Retrieved September 22, 2011, from http://www.lrrd.org/lrrd16/6/sarw16038.htm.

SAS. 2013. SAS OnlineDoc ${ }^{\circledR}$ 9.1.3. in SAS Inc., Cary, NC, USA.

Schröder, A., and K. H. Südekum. 1999. Glycerol as a by-product of biodiesel production in diets for ruminants. in Proc. New 
Horizons for an Old Crop. Proc. 10th Int. Rapeseed Congr, Vitti, D. M. S. S., A. L. Abdalla, J. C. Silva Filho, N. L. del Mastro, Canberra, Australia.

Südekum, K. H. 2007. Co-products from biodiesel production. Pages 201-219 in Recent Advances in Animal Nutrition. P. C. Garnsworthy and J. Wiseman, ed. Nottingham University Press, Nottingham, UK.

Van Soest, P. J., J. B. Robertson, and B. A. Lewis. 1991. Methods for dietary fiber, neutral detergent fiber and nonstarch polysachharides in relation to animal nutrition. J. Dairy Sci. 74:3583-3597. R. Mauricio, E. Oven, and F. Mould. 1999. Misleading relationships between in situ rumen dry mater disappearance, chemical analyzed and in vitro gas production and digestibility, of sugarcane baggage treated with varying levels of electron irradiation and ammonia. Anim. Feed Sci. Technol. 79:145-153.

Waghorn, G. C., and W. C. McNabb. 2003. Consequences of plant phenolic compounds for productivity and health of ruminants. Proc. Nutr. Soc. 62:383-392. 